\title{
9 Bonding through Objectification: The Gendered Effects of Commercial Sex on Male Homosocial Work Culture in Northern Thailand and Beyond
}

\begin{abstract}
In Northern Thailand, visiting sex workers alongside male peers has historically been a bonding technique that enables men to perform masculinity among their male co-workers. While research uncovering men's work-based visits to sex workers is limited, it has been found that men who do business with each other may provide or expect commercial sex visits as part of workplace negotiations; this has been considered "an unremarkable aspect of male professional life" (VanLandingham et al. 1998, 2003). Drawing on one year of ethnographic fieldwork in Northern Thailand, this research utilises the lens of multiple masculinities to assert that workplace bonding in the modern era both perpetuates and challenges gender inequalities.

This chapter first examines the gendered effects of visits to commercial sex establishments among male co-workers. By reviewing methods through which male co-workers perform masculinities in relation to commercial sex, this article will argue that workplace negotiations of manhood through the purchase of commercial sex work affects both men and women. This chapter will conclude by affirming that men who bond through the purchasing of commercial sex create homosocial environments that objectify women and sustain glass ceilings for women in the workplace.
\end{abstract}

\section{Introduction}

It is almost nine p.m. at an unmarked brothel with boarded windows on a busy street near the centre of Chiang Mai. Many passers-by likely assume the shop is a small house; however, male employees stand outside the shop and invite men to come inside and purchase sexual services. A group of approximately 15 women ranging in ages from 20 to 35 sit inside waiting for male customers. When I enter, no customers are present. In this establishment, female employees primarily come from Myanmar. I chat with one of the female employees, who giggles nervously as she recounts coming to Thailand to work in brothels one year ago, when two men in their thirties who are already noticeably drunk

๑ Open Access. (C) 2020 Cassie DeFillipo, published by De Gruyter. (cc) BY-NC-ND This work is licensed under a Creative Commons Attribution-NonCommercial-NoDerivatives 4.0 International License.

https://doi.org/10.1515/9783110651874-010 
enter together. At first, they ask the male employee standing in the doorway why I am in the brothel. Then they jokingly ask me what I cost, telling me I could only be worth 200 baht, or less than $€ 5$ (approximately half the cost of commercial sex in the establishment). They sit down and order a beer to share before starting a conversation with me and my research assistant from across the room. After a few minutes of banter, they then move tables to join us at our seats. These two men in their thirties, who both work in the construction industry, are named Songkarn and Sud. Songkarn and Sud are in the middle of a night of drinking and fun, which in Thailand often involves ventures to commercial sex establishments (Fordham 1995; VanLandingham et al. 1998; Lyttleton 2000). In fact, they had already purchased sexual services this evening and had returned for a second round of sex after the first round ended in orgasm for Songkarn but not for Sud.

While Songkarn and Sud visit the brothel to engage in paid sex, their purpose for visiting commercial sex workers is not solely for sexual gratification; rather, commercial sex establishments such as this brothel are important spaces for male bonding. Considered a legitimate form of male entertainment, especially for men located in urban environments like Chiang Mai (VanLandingham et al. 1998), the majority of men visit sex workers as part of a homosocial group (VanLandingham et al. 1998; Knodel et al. 1996; VanLandingham and Knodel 2007). Commercial sex establishments often serve as homosocial spheres where power is performed by males for other males. Framing commercial sex establishments as a window into Thai gendered practices, this chapter demonstrates that Northern Thailand provides a case study of the complex perpetuation of gender inequality that is shaped by workplace homosociality among men who purchase commercial sex. In order to exemplify the structured inequalities produced by homosocial habits, this chapter will first provide a theoretical discussion of gender performativity and its effects on homosocial work culture. Then, after offering a methodological overview, this project will review the connections between homosociality and commercial sex establishments in Northern Thailand. Next, this chapter will show that patterns of homosocial bonding in Thailand reflect greater global trends. Finally, this chapter discusses the effects of homosociality on men and women in the workplace, evincing that women have difficulties accessing some networking and career building activities as a direct result of male homosocial bonding activities. 


\section{Gender Performativity and Homosocial Work Culture}

Gender as a category is not biological but rather is a social construction (West and Zimmerman 1987; Butler 1990; Connell 1995; Vigoya 2003). Gender is socially constructed through everyday interactions, discourses and institutions (Harvey et al. 2013; Butler 1993; Edley and Wetherell 1995; Kimmel 2004). As such, the masculine and feminine are accomplishments rather than biological dispositions (Butler 1995, 168). The enactment of social constructions of gender can be described as a performance, and performance choices are often based on dominant social norms surrounding gender. Butler $(1990,17)$ explains that "performativity is not a singular act, but a repetition and a ritual, which achieves its effects through its naturalization in the context of a body, understood, in part, as a culturally sustained temporal duration”. Gender is thus more learned than biological, and men often learn how to perform and negotiate masculinities within homosocial settings. Homosociality is most broadly defined as same-sex peer group relationships of a non-sexual nature. Most researchers agree that men do not receive a lifetime membership in homosocial circles (Kiesling 2005; Kitiarsa 2013). Rather, men are beseeched to prove themselves by performing masculinity. In choosing how to perform masculinities for homosocial groups, men de-construct and re-construct diverse masculinities.

Importantly, homosociality does not inevitably perpetuate patriarchy. While many homosocial circles function as spaces where power inequalities are maintained in order to allow for men to perform masculinity, there are examples where male homosocial relationships can build "intimacy, gender equality, and nonhomophobia” (Hammarén and Johansson 2014, 6). For instance, homosociality can serve as an important social support group for men. Flood et al. $(2007,426)$ state, "Men may bond as friends, comrades, family members or lovers in ways that do not subordinate women or other men. Indeed, intimate friendships between men are valuable correctives to men's emotional stoicism and reliance on women's emotional labour". In addition, homosocial groups often provide access to resources (Bailey 1998, 109). Conceptually, homosocial spaces provide opportunities for re-envisioning hegemonic performances of masculinity to more positive forms that do not subordinate women, yet they tend to instead perpetuate patriarchy. This research peels the layers of homosociality in an attempt to understand when and how bonding through commercial sex establishments perpetuates patriarchal and power-wielding forms of masculinities. 


\section{Methodology}

Author and activist Alice Walker $(1983,49)$ states, "I believe the truth about any subject only comes when all sides of the story are put together, and all their different meanings make a new one. Each writer writes the missing parts of the other writer's story". This chapter aims to take the "truth" about workplace visits to commercial sex establishments in Thailand and contrast them to patterns in other parts of the world. Building on research conducted in a range of geographical areas, this paper exemplifies that globalised homosocial processes are capable of, and often do, create workplace barriers for women. This research took place in and around the city of Chiang Mai in Northern Thailand. As an emerging city with a population of approximately 130,000, Chiang Mai is advertised as the "cultural hub" of Thailand where many traditions remain intact, but the city is simultaneously experiencing the effects of Westernisation and modernisation. Consequently, Chiang Mai provides a unique case study of emerging gender performances. This chapter stems from one year of ethnographic experience from February 2016 to February 2017. Through contrasting secondary research reviewing men's homosocial bonding behaviours at commercial sex establishments and other masculinised spaces to data gathered from 60 formal interviews, dozens of informal interviews, and hundreds of hours of participant observations at commercial sex establishments, I argue that performances of masculinities in the globalised world often disempower women at the workplace.

Formal interviews were semi-structured and included questions on sexual habits, gender differences, and attitudes toward commercial sex and other non-marital sexual partners. Interviews ranged in length from 20 minutes to 90 minutes and primarily took place in Thai with a research assistant who also served as a Thai/English translator. There were two exceptions to this rule when English-speaking interviewees asked to conduct the interviews in English. Male and female interviewees had the option to choose a place to meet for the interview, and interviews were conducted in spaces that ensured the privacy and anonymity of the participant. Once transcripts were completed, they were entered into a software program for qualitative analysis. Findings were ascertained by building from 'the 'bottom' up, using the participants' views to build broader themes and generate a theory interconnecting themes" (Creswell and Clark 2017, 23). In accordance with ethics regulations and best practices, all names have been changed in order to protect the identities of research participants. 


\section{Homosociality and Commercial Sex Establishments in Thailand}

Research has estimated that up to 75 percent of Thai heterosexual men have visited sex workers (Shih 1994). The commercial sex industry in Thailand is frequented by Thai men of all ages, ethnic groups, and classes and is often utilised as a space where men negotiate masculine ideals. Arxer (2011) and Bird (1996) both state that homosocial settings such as commercial sex establishments encourage the formation and conservation of hegemonic masculinity, in part through the negation of alternative masculinities. The prominent use of commercial sex workers in Northern Thailand has been linked to homosociality and male bonding activities (VanLandingham et al. 1998; Fordham 1995). In homosocial settings in Northern Thailand, visits to commercial sex establishments stereotypically begin with male peer group gatherings. Not all male get-togethers lead to visiting commercial sex workers, especially in rural areas where fewer opportunities exist to access commercial sex, but throughout modern history male sexual lives have been shaped within peer group settings. VanLandingham et al. (1998, 2007) state:

Since peer interactions generally and commercial sex visitation in particular, are scripted during adolescence in part as an escape from the mundaneness of everyday life, it is not surprising that many of the adult men in our study stressed the added significance that a commercial sex visit can contribute to an otherwise ordinary outing. This added significance seems to be particularly important to some married men as these peer group reunions become less frequent.

Some peer groups are more prone to commercial sex patronage than others, and while some groups of men may refuse to participate in visiting commercial sex establishments other groups visit regularly (VanLandingham et al. 1998, 2000). Some men choose to stop participating in commercial sex after marriage, while others do so frequently. The differences in behaviours do have some intersectional influences, although no research has explored intersectional factors such as class and ethnicity within Thailand in detail. Nonetheless, it has generally been accepted by both men and women that after marriage "men will engage in extra-marital sexual relationships, particularly with commercial sex workers" (Fongkaew 1997, 582).

The HIV epidemic in the 1990s, which was spread primarily through heterosexual commercial sex work, appears to have led to decreasing rates of purchasing sex and increasing acceptance of those who choose not to purchase sex. For instance, Narong is a 23-year-old male student at a technical college where most of his peers are also male. His first experience at a commercial sex 
establishment was with a group of male peers. His older peers paid for him to sit and drink with a woman. He discussed purchasing sex with the woman and even negotiated the price, but Narong decided not to purchase sex because he was afraid of diseases. Himself and one other friend went home while the rest of his peers purchased sex. While Narong experienced autonomy in making choices around when and how to purchase sex, some men do not feel they have the same level of agency. For instance, VanLandingham et al. (1998, 2004) found one participant named Mr. D stated an invitation to purchase commercial sex cannot be easily declined, explaining that he would rather purchase sexual services than risk the punitive consequences. He states: "We have to say yes. It is hard to say no so we simply go with them. We may take a girl into a room and just talk with her. We do it to maintain good will within the group."

The popularity of commercial sex establishments endures because performing masculinities at commercial sex establishments enables men to perform power and differentiate their masculinity to that of other men. Hoang $(2015,15)$ states in relation to Vietnam that, “[m]en's desire for dominance over other men is enacted through the consumption of distinct types of sex workers in different spaces. For male clients, commercial sex workers are products to be consumed in ways that enable them to enact distinction”. The existence of numerous types of brothels, massage parlours and karaoke bars for various types of men, primarily based on class and ethnicity, allows men to enact distinct and diverse performances of masculinity. For instance, there is a line of karaoke bars in one area of the city targeting Shan migrants from Myanmar. The karaoke bars have Shan names, and men who enter can sing Shan music. Thai songs are also offered, so a variety of lower-class and middle-class Thai men visit the establishment regularly. Men may also choose to go to a nearby brothel that serves low-income men and where one hour of sexual services costs between 300 and 500 Thai baht, which is the cost of 5 to 8 meals at inexpensive restaurants. In contrast, men who visit the local massage parlor can expect to pay 1,000 to 1,800 Thai baht plus a tip, which is the equivalent of a monthly heating bill in an apartment or approximately 5 to 10 percent of the average monthly salary. Men with less money or who come from different ethnic backgrounds have the opportunity in Thai culture to perform masculinity through purchasing sex, but they only have access to limited places and have less control over the experience than men with more money. For instance, Ai-dtim is an employee at a karaoke bar that primarily serves groups of male businessmen. According to Ai-dtim, regulars to the establishment include businessmen from Bangkok as well as employees from nearby government offices. Ai-dtim says, "A lot of Thai businessmen who come [. . .] don't have a spending limit. Some individuals might spend 10,000 baht (\$445) in a night and then come back the next night and spend the same amount. They 
spend money like it is nothing. Some groups rent out 10 or 20 women when they come". For the men who visit the karaoke bar where Ai-dtim works, the commercial sex establishment is an extension of the office. A middle-aged businessman named Somchai exemplifies this. Through visiting masculinised spaces such as commercial sex establishments, Somchai performs a hetero-hegemonic form of masculinity for other men. Men who are able to perform hegemonic masculinities hold power (Kimmel 2000), and for Somchai power is performative. For instance, Somchai has a standard tipping routine he undertakes in addition to regular costs. For Dek Sideline (young) girls, or young women who are normally college students who sell sexual services part-time, Somchai gives a 500-baht tip (or \$22) in addition to the purchase price of 2,000 baht (\$88). For other women whose services cost 1,200 (\$53) or 1,500 (\$66) baht, he offers a 200-baht (\$9) tip. In addition, he tips the chairman (a male employee similar to a manager) 200 baht on each visit. "I am treated so well here because I always tip", he explains. "My drink is always full, and I am treated better than other regulars because money makes a difference". For Somchai, visiting the commercial sex establishment allows him to express and negotiate power inequalities through his financial success. According to Hoang $(2015,75)$, when discussing the context of Vietnam, bars are "central to the (re)production of masculinities in a dynamic global context". In complex globalised environments that push men to interweave social traditions global conceptions of masculinity, commercial sex establishments serve as spaces where men can "prove" their manhood through a controlled performance.

\section{A Reflection of Greater Trends? Global Patterns of Homosocial Bonding through Gendered Objectification}

On 23 January 2018, 360 men gathered in the ballroom of one of London's fivestar luxury hotels for a black-tie charity fundraiser. Chef Gino D’Acampo, comedian David Walliams, and former rugby player Liam Botham joined the likes of power-wielding professionals such as Vice-chairman of investment banking at Barclays Makram Azar, hotel chain billionaire Rashid Al Habtoor, and retail billionaire Sir Philip Green (The Guardian 2018). The dinner was an annual even held by the President's Club, which has raised $£ 20$ million for charity over 33 years (BBC 2018). None of the 360 male attendees brought their female partners, and no female leaders in British business, politics, and finance were invited to join the men for the charitable dinner. Instead, the only women in attendance 
were 130 hired hostesses. One woman hired to help at the event was journalist Madison Marriage (2018). She describes the scene:

All of the women were told to wear skimpy black outfits with matching underwear and high heels. At an after-party many hostesses - some of them students earning extra cash - were groped, sexually harassed and propositioned [. . .]. Many of the hostesses were subjected to groping, lewd comments and requests to join diners in bedrooms elsewhere in the Dorchester [. . . ]. Hostesses reported men repeatedly putting hands up their skirts; one said an attendee had exposed his penis to her during the evening.

The event blended professional networking and charitable fundraising with homosocial bonding through the objectification of women. The auction, which ended with a £400,000 bid by Richard Caring to place his name on a new unit at a children's hospital, also included bidding opportunities for a night at the Windmill strip club or a chance to "add spice to your wife" with plastic surgery (Marriage 2018). The event was not just a masculinised space where women were objectified; it was also a space where men networked professionally and acquired career-building opportunities that working women in the business sector were unable to access.

This President's Club fundraiser exemplifies the building of a masculinised space where women as sexual objects serve as tools for male homosocial bonding. Trends toward homosocial bonding through workplace visits to commercial sex establishments, strip clubs, or other similar settings have been noted across many cultures. In 2015 Hoang found that men in Vietnam, both local men and members of the diaspora, utilise commercial sex establishments and the consumption of different types of sex work as a means to negotiate and enact their desire for dominance over other men $(2015,15)$. According to Hoang $(2014,527)$, "[m]en are purchasing status and dignity, and working to protect their precarious positions in the global order". Spaces where men purchase sex and consequently reproduce and negotiate performances of masculinities are central to the production and reproduction of masculinities in a global context $(2015,75)$. Throughout Asia, commercial sex work has been called the sexual custom of Asian men (Matsui and Toyokawa 1996, 35). USAID (2007) found that in Cambodia between 59 and 80 percent of men surveyed reported having sex with commercial sex workers, primarily in brothels. In contrast, one survey found that approximately 37 percent of men in Japan have visited commercial sex establishments at some point in their lives (Anderson and O'Connell Davidson 2003). According to a male Vietnamese participant of Hoang $(2015,57)$, Westerners do not do business in sex establishments such as karaoke bars because "they call it corruption; we call it building trust". However, research is revealing that many men in the West are partaking in homosocial bonding through visits to establishments that frame 
women as sexual objects, although visits to commercial sex establishments are neither normalised nor legalised in many settings; rather, strip clubs and escort services are often utilised by members of businesses for the purpose of networking and entertaining (Jeffreys 2010). For instance, with perhaps as many as 80 percent of male city finance workers in London visiting strip clubs as part of their work, "women in the world of business [. . .] are confronting a new glass ceiling created by their male colleagues' use of strip clubs”, (Fine 2010, 72; Jeffreys 2008). Fine (2010, 71-72) notes that it is becoming increasingly common for clients to be entertained at entertainment venues. She explains that 41 percent of the UK's lap-dancing clubs promote corporate entertainment on their websites, while 86 percent of London clubs offer discreet receipts that let male attendees claim the bill as a company expense. All these examples indicate that amidst a globalising world male homosocial visits to commercial sex establishments, or similar venues that allow for the permissive objectification of women and deter women's entry into homosocial workplace bonding activities, are important aspects of performing masculinities in some cultures and are gaining popularity in others.

\section{Effects of Homosociality on Men and Women in the Workplace}

The effects of homosociality on men and women in the workplace are evident in Thailand. As of 2017, women comprise 45.67 percent of the workforce in Thailand (World Bank 2019). According to the World Bank, 65 percent of lowincome women, 46 percent of middle-income women, and 52 percent of highincome women worked in 2017. However, although a significant portion of the female population is working in Thailand, there is still gender differentiation in the types of jobs men and women are hired for. Interviewees, male interviewees in particular, state that men could work "outside" jobs that are not suitable for women. Other participants, both men and women, believe that men and women could work together but men following the leadership of a women boss is often considered inappropriate or uncomfortable. For instance, according to 22-yearold male psychology student Asnee, whose father works as an engineer, "[t]he subordinates don't listen to the female engineer, even if she is a leader; they listen to the male engineer". Participants expressed that women in positions of power experience difficulty leading men. Interviews stated that commonly both men and women would respect a woman less than a man in the same position. In addition, some research has found that women tend to earn less than men. 
Hansatit $(2014,151)$ says, "[s]ince female executives earn less than their male counterparts, they feel subjected to discrimination in comparison with men having similar qualifications or skills". In contrast, Bui and Permpoonwiwat $(2015,19)$ found that in general gender wage gap in Thailand has narrowed down over the last decades from 14 percent in 1996 to 10 percent in 2006 and then 1 percent in 2013. Despite this seemingly forward movement toward gender equality, Bui and Permpoonwiwat $(2015,19)$ explain that these trends have occurred amidst an increase in gender discrimination. For instance, while improvements in women's education and skill levels have raised their wages, nonetheless "those efforts were eliminated by discrimination". Regardless of efforts to empower women, a diverse range of interviewees who are women still emphasise that they experience negative repercussions of homosociality in their careers and private lives.

Some of the negative repercussions that women experience in the workplace are part and parcel of men's discourses in homosocial settings that tolerate and even encourage the permissive objectification of women. Permissive objectification can be defined as the process where humans view other humans as physical objects. Briñol et al. $(2017,1)$ explain, "[w] hen we focus on the physical aspects of a person (e.g. external appearance), we are less likely to focus on more internal, psychological states". Built on this foundational definition of objectification, permissive objectification is thus where men's choice to objectify women in homosocial settings gives permission to other men to objectify women both within and outside of homosocial settings. This pattern of permissive sexual objectification among men starts in homosocial groups at a young age and tends to linger with men throughout their lives. According to Kimmel (2000, 57), not only do men turn women into sex objects, but the exchange of women as wives is often used to cement alliances among men. While not all men will participate in objectifying women all the time, this permissive objectification allows men to objectify women for the purposes of performing masculinities in homosocial settings. Male interviewees state that in addition to objectifying women when seeking casual sexual partners, they also bond within their male peer groups through talking about women and judging women as physical objects. Men in Thailand also bond by following a code that allows them as men to have sex with numerous partners but assesses women negatively for doing the same. For instance, among one homosocial group, men took pride in having sex with multiple women but simultaneously looked for women who had not lost their "purity" to other members of the group. Ritthirong, a civil servant in his mid-twenties, says: "Yes, men like to hunt the score and tell experiences with friends about getting girls. If I have sex with a girl, I'll tell my friend and he won't have sex with her but he will find other girls. She is used; the men want dignity. It is about men's dignity". Sexual satisfaction comes second to the need to perform masculinities according to the norms of his 
homosocial group. For Ritthirong and his peers, women's bodies are objectified as sexual objects before sex and dirty, undignified objects after sex. It is important to note that male peer groups do not only allow the permissive objectification of women within that homosocial circle; rather, permissive objectification in homosocial peer groups leads to the objectification of women in outside spaces including the workplace because the practice becomes normalised.

Homosocial peer groups often generate power-wielding homosocial assemblies in workplace environments. These assemblies privilege male members while disempowering women and men who are not members in the group. Fine (2010, 70), in discussing women's success in the Western corporate world, holds homosocial masculinised spaces responsible for excluding women from essential business negotiations. She argues:

Unfortunately, the problem for women of being excluded does not end when they leave the office. Depressingly, it is still the case that in many industries it gets worse. At first glance, a round of golf and a trip to the local lap-dancing club may seem to have little in common. They are both leisure activities, it's true, but one is conservative, traditional, and may even entail the wearing of Argyle socks, while the other involves naked women rubbing their genitalia against the fly region of a man's pants. What they share, however, is an environment that provides ample scope for excluding women from valuable client networking opportunities.

Fine problematises workplace homosocial behaviour in all its masculine locations because it excludes women. Women lose valuable opportunities to build trust with co-workers and clients and are simultaneously forced to distance themselves from feminine gender performances that match those of women who have been sexually objectified by men during workplace bonding activities. Perhaps for this reason, women who vie with men for positions of power in the west tend to "put on a compensatory manhood act" (Schrock and Schwalbe 2009), although in Thailand, little research has explored how women negotiate with homosocial masculine powers in the workplace. Women play an important, albeit sexualised, role in allowing men to perform masculinities in masculinised spaces - but it is a controlled role demarcated by men's narratives of women as sexual objects. In some commercial sex establishments in Thailand, for instance, signs at the entrance of establishments explicitly state that Thai women are not allowed inside as customers. This both reinforces men's ability to perform masculinities in homosocial settings through the permissive objectification of women and limits women's workplace opportunities because women are unable to build trust with co-workers and clients in the traditional setting. 
Patterns of homosocial bonding in commercial sex establishments greatly affect women's access to professional networks and career opportunities. In Chiang Mai, women challenge enactments of hegemonic masculinities by entering masculinised workspaces. Despite the limitations that women face, women's access to masculinised workspaces has forced more men to work with women, especially female leaders. Some men are obligated to work alongside women or under women, which is nuancing gender roles and simultaneously creating more fluid gender structures. Informants discussed a variety of situations that they face when men and women work and go to school together. Females in dominantly male university programs discussed poor treatment from men, which hindered them from becoming part of a homosocial group; Chailai, for instance, discussed being bullied by the men in her department. "I don't have a problem with the men in the program, but they like to tease me because I'm small and they like to make me cry. But it makes me strong”. Chailai is one of two women in an otherwise all-male department and is not invited to attend after-hours bonding events. Men often combat change by instilling punitive consequences on women who enter into their space. This is exemplified by the men in Chailai's department who treat Chailai like an outsider. While there are struggles that occur when women enter traditionally male spaces, breaking into institutional masculinised spaces has the potential to hinder men's ability to build homosocial circles that exclude women. These patterns of homosocial bonding, and their effects of inhibiting women from professional networking and career-building opportunities, could potentially be challenged by groups of men who visit alongside peers who are women as has been documented in some research in other Asian settings (Hoang 2015), but such situations are uncommon and were unseen in the hundreds of hours of participant observations completed for this project.

While gender inequalities that oppress women are prominent, gender inequality should also be used to refer to the social inequality and punitive consequences faced by men who are unable to perform masculinity in hegemonic ways. Men experience great pressure to perform masculinity and can be reluctant to contradict other men in homosocial settings - especially because men who cannot or do not perform in homosocial settings tend to face punitive consequences. In Thailand, these consequences can be minimal, such as teasing or loss of friendships, or they can be serious, such as diminished access to jobs. VanLandingham et al. (1998) found that some men expressed a great reluctance to dispute other men, including but not limited to situations where friends purchase sexual services for other friends and in situations where men conduct business together. In settings where men conduct business together, men may 
provide or expect commercial sex visits as part of the negotiation process (VanLandingham et al. 1998, 2003). Men also are pressured by women to perform in homosocial ways and face losing access to potential sexual partners if they are unable to perform a hegemonic masculinity. Men experience social pressure to perform according to the desires of those around them in homosocial groups, but the institutionalisation of these desires has obstructed men's performances of nonhegemonic masculinities. Men who perform subaltern masculinities tend to have peer groups that permit the performances of non-hegemonic masculinities - as can be seen with Narong, whose friends pressure him to purchase sex but allow group members the freedom to not purchase sex and remain part of the male peer group. In contrast, when homosocial groups become institutionalised, both the desire to enter these groups and the punitive consequences men might face for not performing masculinities in accordance with social norms tend to be greater.

Homosocial visits to commercial sex establishments are still common in Northern Thailand, although according to interviewees the level of peer pressure to visit sex establishments has diminished from previous generations as a result of the HIV/AIDS scare that impacted the country in the 1990s. For instance, A-wut says the sex industry is not inherently bad, but he still will not purchase sex. He explains:

\footnotetext{
luck [to buy her].

Cassie : So how do you check if someone has HIV?

I don't know.

Cassie: Is that why you have never gone?

Yes.
}

It is one kind of a job. It is not terrible if [commercial sex workers] don't infect men with HIV. If they have HIV, I will not buy their service. If I don't know if she has HIV, it is bad

The popularity of visiting commercial sex establishments has also been reduced because many young people, both men and women, now visit whisky shops for entertainment and to find casual sex opportunities. While women are likely to visit whisky bars with groups of male and female friends, whisky bars still replicate many aspects of commercial sex establishments for homosocial groups of men. For example, Narong tends to go to the whisky shop to drink beer and whisky with friends, where some of his male peers negotiate (sometimes paid) casual sex with waitresses and female customers. At the whisky shop, the waitress sometimes asks Narong and his friends to have sex with her in exchange for money. Narong's friends sometimes purchase sex and sometimes pay waitresses at whisky bars for 
sex, but Narong never has. Narong attributes his decision not to engage in commercial sex work to fear of diseases, a desire not to spend money, and fear of facing repercussions from his girlfriend. Narong's friends sometimes tease him or try to convince him to purchase sex, but Narong can maintain his friendship with his friendship circle without participating in the group-bonding activity of purchasing sex. Narong's experience in a homosocial group exemplifies that while masculine ideals are known and recognised by male interviewees, the enactment of these masculine ideals vary drastically. This fluidity that Narong and many of the other men negotiate in their chosen performances of masculinities, when permitted in homosocial settings, allows for a wider range of performances of masculinity and less “corrective behaviour” (Plester 2015) for those who perform masculinity in a non-hegemonic manner.

\section{Conclusion}

When Songkarn and Sud take their seats next to me in the brothel, I ask them which women they are interested in. Songkarn looks at the line of women staring intently at him and tells me he wants all of them. His drunk friend, in contrast, grabs my hand and rubs my leg. Sud tells me I should be his girlfriend and drunkenly attempts to woo me. This is a masculinised space, and as a woman who dared entering such a space I am commodified and objectified. For Songkarn and Sud, my presence is permission enough to be objectified. Permissive objectification, where men essentialise the objectification of women's bodies as a biological trait of manhood, may seem harmless when performed amongst homosocial circles in commercial sex establishments. However, the impacts of permissive objectification are much greater and more complex. While it is not inevitably the case, homosocial groups of men tend to "other" women; often this leads to the permissive objectification of women and, consequentially, the social and structural oppression of women in many contexts.

Some forms of performing masculinity in homosocial settings are harmful to both women and men. The men best able to perform masculinity in accordance to the explicit or implicit structures of their homosocial circles tend to be the winners, while the male losers experience oppression in different forms. Through providing a case study of masculinities in Northern Thailand, this chapter asserts that homosocial groups are spaces where men prove and perform their masculinity and where masculine norms can be created, re-created and challenged. More information is needed to identify how widespread visiting commercial sex workers as part of homosocial work culture has become in 
many social and cultural contexts, but what is undeniable is that homosocial work culture, when combined with visits to commercial sex establishments or other spaces where women are sexually objectified, can negatively affect both men and women by preventing them from accessing networking and career building opportunities.

There has been limited discourse pertaining to homosociality's effects on shifting gender roles, especially within institutions. Gender politics are complex and ever-changing in a globalised world, but the lack of discourse surrounding homosociality's negative effects socially and within institutions allows for its continued existence. Homosociality in Chiang Mai has been renegotiated many times over the past 20 years amid rapid growth and incorporation of international influences, yet it is still embedded in many institutions, including legal and academic institutions. Tied with gender norms that define men as leaders, homosociality has diminished the decision-making opportunities available for women. These structures are structurally and legally supported, but more so they are socially supported by the thoughts and actions of Thai men and women. Enloe (2017) reminds us that tools that sustain patriarchy are not just structural or legal in nature; they also appear in the forms of casual essentialisms, parochial analogies, ill-informed guesses, misogynist fears, and dismissive jokes. Challenges to normative performances of masculinities are discouraged within homosocial circles, and this is perhaps the greatest reason why homosociality plays a role in gender equality. Through identifying homosocial circles that perpetuate or re-negotiate gender inequality, noxious ideals of masculinity that diminish career-building opportunities for women can be confronted.

\section{References}

Anderson, Bridget, and Julia O'Connell Davidson. 2003. Is Trafficking in Human Beings Demand Driven?: A Multi-country PilotSstudy. IOM, International Organization for Migration.

Arxer, Steven L. 2011. "Hybrid Masculine Power: Reconceptualizing the Relationship between Homosociality and Hegemonic Masculinity." Humanity \& Society 35(4): 390-422.

Bailey, Alison. 1998. "Privilege: Expanding on Marilyn Frye's' Oppression." Journal of Social Philosophy 29(3): 104-119.

BBC News. 2018. "Presidents Club: Scandal-hit charity dinner organiser quits post." January 25.

Bird, Sharon R. 1996. "Welcome to the men's club: Homosociality and the maintenance of hegemonic masculinity." Gender \& society 10(2): 120-132.

Briñol, Pablo, Richard E. Petty, and Jennifer Belding. 2017. Objectification of people and thoughts: An attitude change perspective. British Journal of Social Psychology 56(2): 233-249. 
Bui, Minh-Tam Thi, and Chompoonuh Kosalakorn Permpoonwiwat. 2015. "Gender Wage Inequality in Thailand: A Sectoral Perspective." The Journal of Behavioral Science 10(2): 19-36.

Butler, Judith. 1990. "Gender trouble, feminist theory, and psychoanalytic discourse." Feminism/postmodernism 327: $\mathrm{x}$.

Butler, Judith. 1993. "Critically Queer." GLQ: A Journal of Lesbian and Gay Studies 1(1): 17-32.

Butler, Judith. 1995. "Melancholy Gender - Refused Identification.” Psychoanalytic Dialogues 5(2): $165-180$.

Connell, Raewyn. 1995. Masculinities. Cambridge: Cambridge University Press.

Creswell, John W., and Vicki L. Plano Clark. 2017. Designing and conducting mixed methods research. Thousand Oaks, CA: Sage.

Edley, Nigel, and Margaret Wetherell. 1995. Men in Perspective. Pearson Education Limited.

Enloe, Cynthia. 2017. The Big Push: Exposing and Challenging the Persistence of Patriarchy. Berkeley: University of California Press.

Fine, Cordelia. 2010. Delusions of Gender: How our Minds, Society, and Neurosexism Create Difference. New York: Norton.

Flood, Michael, Judith Kegan Gardiner, Bob Pease, and Keith Pringle. 2007. International Encyclopedia of Men and Masculinities. London: Routledge.

Fongkaew, Warunee. 1997. "Sexuality, and gender norms among Thai teenagers: problems and solutions." Community-based programs for adolescent sexual health and domestic violence against women. Nakhon Pathom: Center for Health Policy Studies, Faculty of Social Sciences and Humanities, Mahidol University.

Fordham, Graham. 1995. "Whisky, Women and Song: Men, Alcohol and AIDS in Northern Thailand.” The Australian Journal of Anthropology 6(1-2): 154-177.

The Guardian. 2018. "Presidents Club: who was invited to the all-male charity gala?" January 25.

Hammarén, Nils, and Thomas Johansson. 2014. "Homosociality: In between power and intimacy.” Sage Open 4(1): 2158244013518057.

Hansatit, Patcharin. 2014. "A study on gender inequality in Thailand: career experience of Thai female managers.” Phd Diss., Southern Cross University, Lismore, Australia.

Hoang, Kimberly Kay. 2014. "Flirting with Capital: Negotiating Perceptions of Pan-Asian Ascendency and Western Decline in Global Sex Work." Social Problems 61(4): 507-529.

Harvey, Laura, Jessica Ringrose, and Rosalind Gill. 2013. "Swagger, Ratings and Masculinity: Theorising the Circulation of Social and Cultural Value in Teenage Boys' Digital Peer Networks." Sociological Research Online 18(4): 1-11.

Hoang, Kimberly Kay. 2015. Dealing in Desire: Asian Ascendancy, Western Decline, and the Hidden Currencies of Global Sex Work. Berkeley: University of California Press.

Jeffreys, Sheila. 2010. "The sex industry and business practice: An obstacle to women's equality." Women's Studies International Forum 33(3): 274-282.

Kiesling, Scott Fabius. 2005. "Homosocial desire in men's talk: Balancing and re-creating cultural discourses of masculinity." Language in Society 34(5): 695-726.

Kimmel, Michael. 2000. The Gendered Society. Oxford: Oxford University Press.

Kimmel, Michael. 2004. "Masculinity as Homophobia: Fear, Shame, and Silence in the Construction of Gender Identity." Race, Class, and Gender in the United States: An Integrated Study 81: 93.

Kitiarsa, Pattana. 2013. "Of Men and Monks: The Boxing-Buddhism Nexus and the Production of National Manhood in Contemporary Thailand.” New Mandala Blog 2. 
Knodel, John, Mark VanLandingham, Chanpen Saengtienchai, and Anthony Pramualratana. 1996. "Thai views of sexuality and sexual behaviour." Health Transition Review 6(2): 179-201.

Lyttleton, Chris. 2000. Endangered Relations. Boca Raton: CRC Press.

Marriage, Madison. 2018. "Men Only: Inside the charity fundraiser where hostesses are put on show." Financial Times, January 24. Accessed March 10, 2019.

Matsui, Yaori, and Noriko Toyokawa. 1999. Women in the New Asia: From Pain to Power. ZED books.

Plester, Barbara. 2015. “'Take it like a man!': Performing hegemonic masculinity through organizational humour." Ephemera 15(3): 537-559.

Schrock, Douglas, and Michael Schwalbe. 2009. "Men, Masculinity, and Manhood Acts." Annual review of sociology 35: 277-295.

Shih, J. 1994. "A plague in prostitution: HIV and AIDS in Thailand." Rhode Island Medicine 77 (5): 145-149.

USAID, “Cambodia HIV/AIDS Technical Support: Technical Assistance and Support Contract 3 (TASC3) Indefinite Quantity Contract Section A - Request for Task Order Proposal (RFTOP).” Accessed March 10, 2007. www.usaid.gov.

VanLandingham, Mark, John Knodel, Chanpen Saengtienchai, and Anthony Pramualratana. 1998. "In the company of friends: peer influence on Thai male extramarital sex." Social Science \& Medicine 47(12): 1993-2011.

VanLandingham, Mark, and John Knodel. 2007. "Sex and the Single (Older) Guy: Sexual Lives of Older Unmarried Thai Men During the AIDS Era." Journal of Cross-cultural Gerontology 22(4): 375-388.

Vigoya, Mará Viveros. 2003. “Orientaciones íntimas en las primeras experiencias sexuales y amorosas de los jóvenes. Reflexiones a partir de algunos estudios de casos colombianos." Varones adolescentes: género, identidades y sexualidades en América Latina: 115.

Walker, Alice. 1983. "Beauty: When the other dancer is the self." In In Search of Our Mothers' Gardens: Womanist Prose. Michigan: Harcourt Brace and Jovanovich.

West, Candace, and Don H. Zimmerman. 1987. “Doing gender.” Gender \& society 1(2): 125-151.

World Bank. "Labor Force Participation Rate, female.” Accessed 3 March, 2019. Retrieved from https://data.worldbank.org/indicator/SL.TLF.CACT.FE.ZS

World Bank. "Proportion of seats held by women in National Parliament (\%)." Accessed 23 January, 2019. Retrieved from https://data.worldbank.org/indicator/SG.GEN.PARL.ZS 
